DOI: https://doi.org/10.31933/jimt.v2i5 Received: 17 April 2021, Revised: 25 Mei 2021, Publish: 4 Juli 2021

JIMT
JURNAL ILMU MANAJEMEN
TERAPII

\title{
DETERMINASI EARNING PER SHARE DAN RETURN SAHAM : ANALISIS RETURN ON ASSET, DEBT TO EQUITY RATIO, DAN CURRENT RATIO
}

\author{
Badzlina Balqis \\ Universitas Mercu Buana, Jakarta, Indonesia, badzlinab@gmail.com
}

\section{Corresponding Author: Badzlina Balqis}

\begin{abstract}
Abstrak: Pasar modal dapat didefinisikan sebagai pasar yang memperjualbelikan berbagai instrumen keuangan jangka panjang, baik surat utang (obligasi), saham, reksa dana, maupun instrumen lainnya. Return saham merupakan hasil yang diperoleh dari investasi. Tingginya pendapatan atau laba yang diperoleh perusahaan dapat meningkatkan kepercayaan investor terhadap perusahaan tersebut akan return saham yang diharapkan. EPS dapat dijadikan sebagai indikator tingkat nilai perusahaan dan merupakan salah satu cara untuk mengukur keberhasilan dalam mencapai keuntungan bagi para pemilik saham dalam perusahaan. Hasil dari literature review ini adalah: 1) ROA berpengaruh terhadap EPS; 2) ROA berpengaruh terhadap return saham; 3) DER berpengaruh terhadap EPS; 4) DER berpengaruh terhadap return saham; 5) CR berpengaruh terhadap EPS; 6) CR berpengaruh terhadap return saham; 7) EPS berpengaruh terhadap return saham
\end{abstract}

Kata Kunci: ROA, DER, CR, EPS, dan return saham

\section{PENDAHULUAN}

Pasar modal dapat didefinisikan sebagai pasar yang memperjualbelikan berbagai instrumen keuangan jangka panjang, baik surat utang (obligasi), saham, reksa dana, maupun instrumen lainnya. Pasar modal memfasilitasi berbagai sarana dan prasarana kegiatan jual beli dan kegiatan terkait lainnya, dimana didalamnya mencakup sarana pendanaan bagi perusahaan maupun institusi lainnya serta sarana bagi kegiatan berinvestasi yang dilakukan oleh investor. Transaksi jual beli saham merupakan salah satu bentuk investasi favorit yang dilakukan oleh banyak investor, karena mendapatkan keuntungan yang menjanjikan. Dalam hal ini investor memilih investasi yang mendapatkan keuntungan baginya dengan tingkat risiko yang kecil (Pandji, 2019). Hal ini bergantung pada setiap harga pada masing-masing harga saham yang kerap berubah dari waktu ke waktu, atau biasa dikenal sebagai data runtun waktu (time series).

Saham dapat didefinisikan sebagai tanda penyertaan modal seseorang atau pihak (badan usaha) dalam suatu perusahaan atau perseroan terbatas (Nurmasari, 2018). Saham merupakan instrument investasi yang banyak dipilih para investor karena mampu memberikan tingkat keuntungan yang menarik. Pada dasarnya, ada dua keuntungan yang diperoleh investor dengan membeli atau memiliki saham yaitu mendapatkan capital gain dan dividen yang diperoleh 
setiap tahunnya. Keuntungan ini bisa diperoleh investor apabila perusahaan tersebut memiliki kinerja keuangan yang baik. Oleh sebab itu, dalam melakukan transaksi saham di pasar modal, para investor harus teliti dalam mengambil suatu keputusan, baik keputusan membeli, menjual, maupun mempertahankan saham tersebut. Salah satu faktor yang perlu dipertimbangkan dalam membuat dan mengambil keputusan investasi adalah faktor harga saham. Pertimbangan harga saham menjadi sangat penting bagi pelaku pasar, karena harga saham mencerminkan nilai perusahaan. Semakin tinggi harga saham berarti semakin tinggi pula nilai perusahaan juga semakin tinggi pendapatan atau laba yang diperoleh dan sebaliknya. Tingginya pendapatan atau laba yang diperoleh perusahaan dapat meningkatkan kepercayaan investor terhadap perusahaan tersebut akan return saham yang diharapkan. Kepercayaan itulah yang dapat memberikan keputusan investasi kepada investor untuk membeli saham perusahaan tersebut. Tujuan para investor untuk membeli saham perusahaan tidak hanya mengharapkan keuntungan atau return saham dalam jangka pendek saja, tetapi juga dalam jangka panjang. Semakin besar return saham yang diharapkan, maka semakin besar pula risiko yang akan diterima.

Return saham merupakan hasil yang diperoleh dari investasi. Harapan untuk memperoleh return juga terjadi dalam aset finansial. Suatu aset finansial menunjukkan kesediaan investor menyediakan sejumlah dana pada saat ini untuk memperoleh sebuah aliran dana pada masa yang akan datang sebagai kompensasi atas faktor waktu selama dana ditanamkan dan risiko yang ditanggung. Dengan demikian para investor sedang mempertaruhkan suatu nilai sekarang untuk sebuah nilai yang diharapkan pada masa mendatang. Dalam konteks manajemen investasi, return atau tingkat keuntungan merupakan imbalan yang diperoleh dari investasi (Legiman, 2015).

Earning per Share (EPS) merupakan rasio yang menunjukkan seberapa besar keuntungan (return) yang diperoleh investor atau pemegang saham per saham dengan cara membagi laba bersih setelah pajak dengan jumlah saham biasa yang beredar. EPS dapat dijadikan sebagai indikator tingkat nilai perusahaan dan merupakan salah satu cara untuk mengukur keberhasilan dalam mencapai keuntungan bagi para pemilik saham dalam perusahaan (Badruzaman, 2017). Semakin besar EPS maka akan semakin banyak investor yang tertarik unutk melakukan investasi pada perusahaan tersebut, sehingga akan mengakibatkan permintaan akan saham meningkat dan harga saham akan meningkat yang kemudian akan mempengaruhi return saham perusahaan tersebut (Hermawan, 2012).

Berdasarkan uraian latar belakang yang telah dikemukakan di atas, maka penulis tertarik untuk melakukan literature review tentang "Determinasi Earning per Share dan Return Saham: Analisis Return on Asset, Debt to Equity Ratio, dan Current Ratio". Variabel yang digunakan yaitu Return on Asset, Debt to Equity Ratio, dan Current Ratio.

\section{KAJIAN PUSTAKA}

\section{Earning per Share (EPS)}

Earning per Share (EPS) merupakan perbandingan antara laba bersih setelah pajak pada satu tahun buku dengan jumlah saham yang diterbitkan. EPS menunjukkan seberapa besar keuntungan yang diberikan kepada investor dari setiap lembar saham yang dimilikinya. Secara sederhana, EPS menggambarkan jumlah uang yang diperoleh untuk setiap lembar saham. Rasio ini merupakan yang paling sering dianalisis dan dikutip. Alasan utama EPS menjadi fokus utama dibandingkan laba adalah karena tujuan perusahaan adalah memaksimalkan kesejahteraan pemegang saham. Nilai EPS yang tinggi merupakan daya tarik bagi investor. Semakin tinggi nilai EPS, maka kemampuan perusahaan untuk memberikan pendapatan kepada pemegang sahamnya semakin tinggi. 
Earning per Share (EPS) sudah banyak diteliti oleh peneliti sebelumnya diantaranya oleh (Amyulianthy, 2016), (Prabath, 2014), (Putro, 2020), (Wartono, 2018), (Sunaryo, Supriatna, \& Adiyanto, 2019), (Umam, Wijayanto, \& Kodir, 2019), (Borromeu \& Naitian, 2013), dan (Uno \& Barlianta, 2014).

\section{Return Saham}

Return merupakan hasil yang diperoleh dari investor yang dapat berupa realisasi yang sudah terjadi dan return ekspektasi yang diharapkan akan terjadi dimasa mendatang. Investor harus melakukan penilaian harga saham terlebih dahulu agar dapat memperoleh tingkat pengembalian saham (return) dan keuntungan yang sesuai dengan yang diharapkan. Menurut Hartono (2010), return saham adalah tingkat pengembalian saham atas investasi yang dilakukan oleh investor. Menurut Fahmi (2012), return adalah keuntungan yang diperoleh oleh perusahaan, individu, dan institusi dari hasil kebijakan investasi yang dilakukannya.

Saham dikenal dengan karakteristik high risk - high return. Artinya saham merupakan surat berharga yang memberikan peluang keuntungan tinggi namun juga berpotensi risiko tinggi. Saham memungkinkan pemodal untuk mendapatkan return berupa capital gain jika harga saham sekarang (Pt) lebih tinggi dari harga saham periode sebelumnya (Pt-1). Namun, seiring dengan berfluktuasinya harga saham, ada kalanya pemodal harus menjual saham dengan harga jual lebih rendah daripada harga beli, maka hal tersebut disebut dengan capital loss. Secara matematis, formulasi return saham dapat dirumuskan sebagai berikut:

$$
\boldsymbol{R}_{t}=\frac{\boldsymbol{P}_{t}-\boldsymbol{P}_{t-1}}{\boldsymbol{P}_{t-1}} x \mathbf{1 0 0} \%
$$

Return saham sudah banyak diteliti oleh peneliti sebelumnya diantaranya oleh (Nurdin \& Emillia, 2018), (Chikmah, Lailatul, Yuliana, \& Indah, 2020), (Azhari \& Fauzan, 2020), (Fuad \& Mughni, 2018), (Ferdianegara, 2020), (Purnama, Tubagus, \& Asnawi, 2018), (Hariyanto \& Dedi, 2017), dan (Purnamasari \& Imas, 2011).

\section{Return on Asset (ROA)}

Return on Asset (ROA) merupakan rasio yang digunakan untuk mengukur kemampuan perusahaan dalam menghasilkan laba yang berasal dari aktivitas investasi. Rasio ini digunakan untuk mengukur kemampuan manajemen dalam memperoleh keuntungan secara keseluruhan. Semakin besar ROA, maka semakin besar pula tingkat keuntungan yang dicapai oleh perusahaan tersebut dan semakin baik pula posisi perusahaan tersebut dari segi penggunaan aset.

Semakin tinggi rasio ini, maka semakin baik produktivitas aset dalam memperoleh keuntungan bersih. Hal ini akan meningkatkan daya tarik perusahaan kepada investor. Peningkatan daya tarik perusahaan menjadikan perusahaan tersebut semakin diminati oleh investor, karena tingkat pengembalian atau deviden akan semakin besar. Hal ini juga akan berdampak pada harga saham dari perusahaan tersebut di pasar modal yang akan semakin meningkat sehingga ROA akan berpengaruh terhadap harga saham perusahaan. Angka ROA dapat dikatakan baik apabila $>2 \%$. Besarnya nilai ROA dapat dihitung dengan rumus berikut ini.

$$
\text { ROA }=\frac{\text { Laba Setelah Pajak }}{\text { Total Asset }} \times 100 \%
$$

Return on Asset (ROA) sudah banyak diteliti oleh peneliti sebelumnya diantaranya oleh (Narayan, 2015), (Atidhira \& Yustina, 2017), (Tamuunu, 2015), (Insani \& Nurlailly, 2019), 
(Alhazami, 2019), (Salam \& Aam, 2020), (Firmansyah, 2018), (Hapsari \& Pungky, 2013), (Hardiningsih \& Pancawati, 2017).

\section{Debt to Equity Ratio (DER)}

Debt to Equity Ratio (DER) menggambarkan perbandingan utang dengan ekuitas dalam pendanaan perusahaan dan menunjukkan kemampuan modal sendiri perusahaan untuk memenuhi kewajibannya. DER merupakan salah satu rasio yang dibutuhkan oleh investor. Investor perlu mengetahui kesehatan perusahaan melalui perbandingan antara modal pinjaman dan modal sendiri (Yuni, 2016). Investor cenderung menghindari saham-saham yang memiliki nilai DER yang tinggi karena nilai DER yang tinggi mencerminkan risiko perusahaan yang relatif tinggi.

Semakin tinggi DER mencerminkan semakin tinggi tingkat hutang perusahaan. Tingginya rasio ini menunjukkan komposisi total hutang semakin besar dibandingkan dengan total modal sendiri sehingga meningkatkan risiko yang diterima investor sebagai akibat dari beban bunga hutang yang ditanggung oleh perusahaan. Hal ini akan menyebabkan turunnya harga saham yang selanjutnya berdampak terhadap turunnya return saham perusahaan (Puspitadewi \& Rahyuda, 2016)

Debt to Equity Ratio (DER) sudah banyak diteliti oleh peneliti sebelumnya diantaranya oleh (Menhard, 2018), (Prihantini, 2017), (Sugiarto \& Agung, 2011), (Septina \& Siska, 2019), (Budiharjo \& Roy, 2018), (Defrizal, 2015), (Adiesti \& Vanida, 2013), (Simanjuntak \& John, 2017), (Habiburrahman, 2015).

\section{Current Ratio (CR)}

Current Ratio (CR) atau rasio lancar merupakan rasio untuk mengukur kemampuan perusahaan dalam membayar kewajiban jangka pendek atau hutang yang segera jatuh tempo pada saat ditagih secara keseluruhan. Dengan kata lain, seberapa banyak aset lancar yang tersedia untuk menutupi kewajiban jangka pendek yang segera jatuh tempo (Kasmir, 2014). Apabila aset lancarnya melebihi hutang lancarnya, dapat diperkirakan pada saat dilakukan likuiditas, aset lancar terdapat cukup kas ataupun yang dapat dikonversikan menjadi uang kas di dalam waktu singkat, sehingga dapat memenuhi kewajibannya. Perhitungan rasio lancar dilakukan dengan cara membandingkan antara total aset lancar dengan total utang lancar. Rumus dari Current Ratio yaitu :

$$
\text { Current Ratio (Rasio Lancar) }=\frac{\text { Current Assets (Aset Lancar) }}{\text { Current Liabilites (Utang Lancar) }}
$$

Dari hasil pengukuran rasio, apabila rasio lancar rendah, dapat dikatakan bahwa perusahaan kurang modal untuk membayar hutang. Namun, apabila hasil pengukuran rasio tinggi, belum tentu kondisi perusahaan sedang baik. Hal ini dapat terjadi karena kas tidak digunakan sebaik mungkin (Harahap, 2013).

Current Ratio (CR) sudah banyak diteliti oleh peneliti sebelumnya diantaranya (Candradewi \& Reina, 2016), (Subarjo, 2015), (Hamdani \& Ikmal, 2018), (Rois \& Pandiya, 2019), (Wicaksono \& Maheranto, 2016), (Tarmizi \& Rosmiati, 2018), (Karla \& Roisantri, 2020), (Ilmiyono \& Agung, 2019). 


\section{METODE PENELITIAN}

Jenis penelitian yang digunakan dalam penelitian ini adalah metode penelitian kuantitatif dengan pendekatan deskriptif. Metode penelitian kuantitatif adalah metode penelitian yang didasarkan pada filsafat positivism, digunakan dalam meneliti sample dan populasi penelitian, teknik pengambilan sampel pada umumnya dilakukan secara random, pengumpulan data menggunakan instrumen penelitian, analisis data bersifat kuantitatif/statistik dengan tujuan untuk menguji hipotesis yang ditentukan (Sugiyono, 2009). Adapun penelitian deskriptif merupakan metode yang bertujuan untuk menjelaskan atau mendeskripsikan suatu peristiwa, keadaan, objek atau orang, atau segala sesuatu yang terkait dengan variable-variabel yang bisa dijelaskan baik menggunakan angka-angka maupun kata-kata. Penelitian deskriptif dalam penelitian ini dimaksudkan untuk mendapatkan gambaran dan keterangan-keterangan terkait pengaruh Return on Asset, Debt to Equity Ratio, Current Ratio terhadap Earning per Share dan Return Saham.

\section{HASIL DAN PEMBAHASAN}

\section{Pengaruh Return on Asset (ROA) terhadap Earning per Share (EPS)}

Return on Asset (ROA) adalah bentuk dari rasio profitabilitas yang dapat mengukur kemampuan perusahaan dengan keseluruhan dana yang ditanamkan dalam aktiva dan digunakan untuk operasi perusahaan dalam menghasilkan keuntungan (Munawir, 2007). Dalam kaitannya dengan EPS, semakin tinggi ROA, maka laba yang akan dibagikan kepada para pemegang saham juga akan semakin tinggi, begitu pun sebaliknya. Hal tersebut dikarenakan ROA merupakan pengembalian yang dihasilkan dari pengelolaan aset yang dimiliki perusahaan, baik aset sendiri maupun aset yang berasal dari investor. Besarnya rasio pengembalian atas pengelolaan aset ini dapat diketahui melalui hasil perhitungan antara besarnya laba bersih dibagikan dengan besarnya total aset/total aktiva perusahaan dalam satu periode tertentu (Diaz, 2014).

\section{Pengaruh Return on Asset (ROA) terhadap Return Saham}

Return on asset (ROA) merupakan rasio yang mengukur kemampuan menghasilkan laba dari total aktiva yang digunakan. Semakin besar nilai dari ROA maka semakin baik perusahaan menggunakan asetnya untuk menghasilkan laba. Hal tersebut tentunya membuat investor menjadi tertarik untuk membeli saham perusahaan serta akan berdampak pada harga saham yang semakin meningkat dan diikut dengan tingkat pengembalian return saham yang tinggi. Anwaar (2016) telah melakukan penelitian mengenai pengaruh ROA terhadap return saham yang menunjukkan bahwa ROA memiliki pengaruh terhadap return saham.

\section{Pengaruh Debt to Equity Ratio (DER) terhadap Earning per Share (EPS)}

Debt to Equity Ratio (DER) berpengaruh signifikan terhadap Earning per Share (EPS) karena perusahaan sudah mampu untuk mengefektifkan dalam menghasilkan keuntungan di periode yang akan dating. Keuntungan tersebut tidak hanyak digunakan untuk menutupi utang yang dimiliki sehingga mengurangi jumlah keuntungan yang didapatkan. Sehingga hal tersebut bisa dianggap perusahaan memiliki kinerja yang bagus dan mempengaruhi keuntungan dari setiap lembar saham yang diterima oleh investor, karena secara tidak langsung jika keuntungan perusahaan besar, maka EPS yang dibagikan juga meningkat (Anwar, 2017)

\section{Pengaruh Debt to Equity Ratio (DER) terhadap Return Saham}

Debt to Equity Ratio (DER) adalah rasio yang menunjukkan hubungan antara total kewajiban dengan total ekuitas yang diberikan oleh pemilik perusahaan. Semakin tinggi DER 
menunjukkan semakin besar kewajiban perusahaan dibanding dengan ekuitas yang dimiliki perusahaan. Semakin tinggi DER cenderung menurunkan return saham, karena tingkat hutang yang semakin tinggi menunjukkan beban bunga perusahaan akan semakin besar dan mengurangi keuntungan (Siburian, 2013).

\section{Pengaruh Current Ratio (CR) terhadap Earning per Share (EPS)}

Current Ratio (CR) mengukur kemampuan perusahaan dalam membayar kewajiban jangka pendeknya dengan menggunakan aktiva lancarnya. Posisi likuiditas dari suatu perusahaan merupakan faktor penting yang harus dipertimbangkan sebelum mengambil keputusan untuk menetapkan besarnya dividen yang akan dibayarkan kepada para pemegang saham. Semakin tinggi tingkat likuiditas suatu perusahaan, maka tingkat laba yang diterima investor juga semakin besar sehingga dapat ditarik kesimpulan bahwa current ratio memiliki pengaruh positif terhadap earning per share (Mudjijah, 2015).

\section{Pengaruh Current Ratio (CR) terhadap Return Saham}

Current Ratio (CR) merupakan rasio yang digunakan untuk mengukur dan mengetahui sejauh mana perusahaan dapat menjaga likuiditasnya. Semakin tinggi nilai CR, maka semakin likuid perusahaan tersebut dan menjadi daya tarik tersendiri bagi investor untuk menanamkan modalnya pada perusahaan yang selanjutnya harga saham perusahaan tersebut akan meningkat dan menyebabkan return saham juga meningkat. Jabbari (2014) telah melakukan penelitian mengenai pengaruh $\mathrm{CR}$ terhadap return saham yang menunjukkan bahwa $\mathrm{CR}$ memiliki pengaruh terhadap return saham.

\section{Pengaruh Earning per Share (EPS) terhadap Return Saham}

Earning per Share (EPS) merupakan rasio keuangan yang digunakan para investor dalam menganalisis kemampuan dari perusahaan untuk mendapatkan laba dari saham yang dipilih. Meningkatnya nilai EPS dapat diartikan bahwa perusahaan dapat menghasilkan keuntungan bersih per lembar sahamnya. Hal tersebut akan berdampak pada kenaikan harga saham diikuti dengan tingkat pengembalian return yang tinggi. Shakeel (2018) telah melakukan penelitian mengenai pengaruh EPS terhadap return saham yang menunjukkan bahwa EPS memiliki pengaruh terhadap return saham.

\section{Conceptual Framework}

Berdasarkan rumusan masalah penulisan artikel ini dan kajian studi literature review baik dari buku dan artikel yang relevan, maka diperoleh kerangka artikel ini seperti di bawah ini.

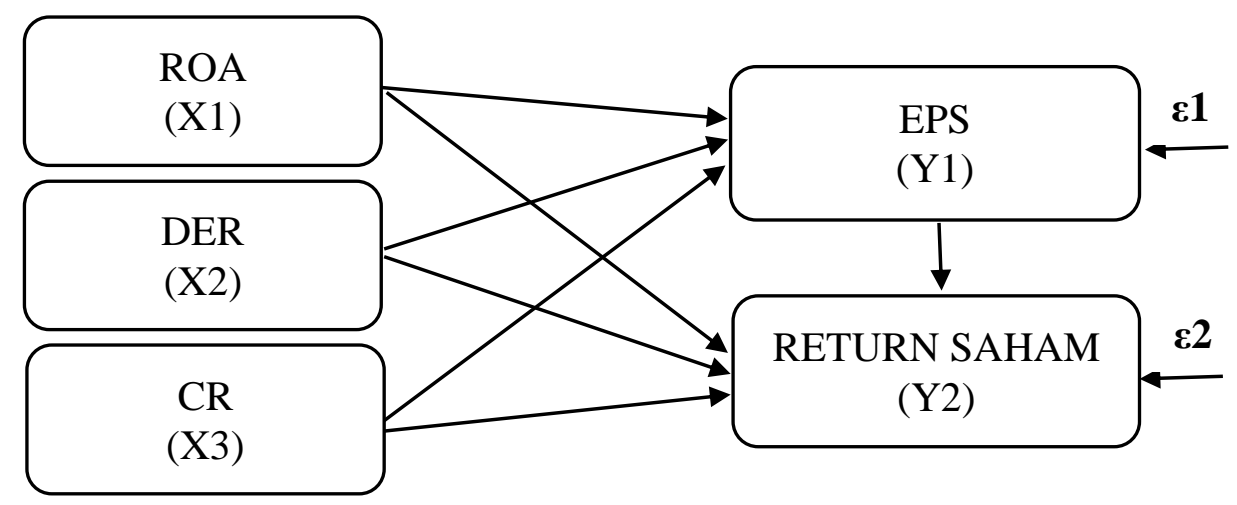

Gambar 1 : Conceptual Framework

KESIMPULAN DAN SARAN

Kesimpulan 
Berdasarkan rumusan artikel, hasil, dan pembahasan, maka dapat dirumuskan hipotesis untuk riset selanjutnya sebagai berikut:

1. ROA berpengaruh terhadap EPS

2. ROA berpengaruh terhadap return saham

3. DER berpengaruh terhadap EPS

4. DER berpengaruh terhadap return saham

5. CR berpengaruh terhadap EPS

6. CR berpengaruh terhadap return saham

7. EPS berpengaruh terhadap return saham

\section{Saran}

Berdasarkan kesimpulan di atas, maka saran pada artikel ini adalah bahwa masih banyak faktor lain yang mempengaruhi earning per share (EPS) dan return saham, selain dari return on asset, debt to equity ratio, dan current ratio. Oleh karena itu masih diperlukan kajian lebih lanjut untuk mencari faktor-faktor lain apa saja yang dapat mempengaruhi earning per share (EPS) dan return saham selain yang di teliti pada artikel ini.

\section{DAFTAR RUJUKAN}

Adiesti, \& Vanida, L. (2013). Pengaruh Faktor-Faktor Fundamental Terhadap Return Saham. Jurnal Ilmiah Universitas Bakrie.

Alhazami, L. (2019). Determinasi Ratio Profitabilitas pada Return Saham Studi Kasus Perusahaan Pertambangan di Bursa Efek Indonesia (BEI) Tahun 2013-2017. Jurnal Mitra Manajemen.

Amyulianthy, R. \&. (2016). The Effect of Economic Value Added and Earning per Share to Stocks Return (Panel Data Approachment). International Journal of Business and Management Invention Vol.5 Issue 2.

Anwaar, M. (2016). Impact of Firms' Performance on Stock Return (Evidence From Listed Companies Of FTSE-100 Index London). Global Journal of Management and Business Research: D Accounting and Auditing, Vol.16 Issue 1.

Anwar, S. (2017). Analisis Pengaruh Debt to Equity Ratio (DER), Return on Asset (ROA), Current Ratio (CR), Total Assets Turnover (TATO), dan Price Earnings Ratio (PER) Terhadap Earnings per Share (EPS). Simki-Economic Vol.01 No.03.

Atidhira, A., \& Yustina, A. (2017). The Influence of Return on Asset, Debt to Equity Ratio, Earnings per Share, and Company Size on Share Return in Property and Real Estate Companies. Journal of Applied Accounting and Finance Vol.1 No.2.

Azhari, \& Fauzan. (2020). Pengaruh Beta Terhadap Return Saham pada Perusahaan Sektor Perdagangan, Jasa dan Investasi. Jurnal Ilmu Manajemen.

Badruzaman, J. (2017). Pengaruh Earning per Share Terhadap Harga Saham. Jurnal Akuntansi Vol.12 No.1. 
Borromeu, \& Naitian, I. (2013). Pengaruh Rasio Keuangan Terhadap Earning per Share (EPS) pada Perusahaan Perbankan yang Terdaftar di Bursa Efek Indonesia. Jurnal Manajemen dan Bisnis.

Budiharjo, \& Roy. (2018). Pengaruh Profitabilitas dan Leverage Keuangan Terhadap Return Saham pada Perusahaan Industri Konsumsi Makanan dan Minuman yang Terdaftar di Bursa Efek Indonesia. Jurnal Profita.

Candradewi, \& Reina, M. (2016). Pengaruh Kinerja Keuangan Terhadap Return Saham pada Perusahaan LQ45 di BEI: Analisis Regresi Data Panel. E-Journal Ekonomi dan Bisnis Universitas Udayana.

Chikmah, Lailatul, A., Yuliana, \& Indah. (2020). Pengaruh Profitabilitas Terhadap Return Saham dengan Suku Bunga sebagai Variabel Moderating (Saham Sektor Anek Industri Periode 2016-2018). Journal of Management Review.

Defrizal. (2015). Analisis Pengaruh Rasio Keuangan Terhadap Return Saham (Studi pada Saham-Saham Sektor Manufaktur yang Terdaftar di Bursa Efek Indonesia Tahun 20082012). Jurnal Manajemen dan Bisnis.

Diaz, R. (2014). Pengaruh Return on Assets (ROA) dan Return on Equity (ROE) Terhadap Earning per Share (EPS) Pada Perusahaan Asuransi yang Terdaftar di Bursa Efek Indonesia. Jurnal Manajemen \& Bisnis Vol.14 No.02.

Fahmi, I. (2012). Analisis Kinerja Keuangan. Bandung: Alfabeta.

Ferdianegara, M. (2020). Pengaruh Price Earning Ratio, Return on Equity, dan Debt to Equity Ratio Terhadap Return Saham. Jurnal Indonesia Sosial Teknologi.

Firmansyah. (2018). Pengaruh ITO, DER, ROA Terhadap Return Saham pada Kompas 100 di BEI 2013-2015. JWEM (Jurnal Wira Ekonomi Mikroskil).

Fuad, \& Mughni. (2018). Analisis Pengaruh Rasio Keuangan Terhadap Return Saham PT. Adhi Karya (Persero) Tbk. Jurnal Samudra Ekonomi dan Bisnis.

Habiburrahman. (2015). Analisis Pengaruh Rasio Keuangan Terhadap Return Saham (Studi Pada Saham-Saham Sektor Agiculture, Forestry and Fishing yang Terdaftar di Bursa Efek Indonesia Periode 1998-2014). Jurnal Manajemen dan Bisnis.

Hamdani, \& Ikmal. (2018). Pengaruh Return on Investment (ROI), Economic Value Added (EVA) dan Current Ratio (CR) Terhadap Return Saham. Jurnal Al-Iqtishad.

Hapsari, \& Pungky. (2013). Analisis Pengaruh EVA dan ROA Terhadap Return Saham pada Industri Konsumsi di Bursa Efek Indonesia. EQUILIBRIUM : Jurnal Ilmiah Ekonomi dan Pembelajarannya.

Harahap, S. S. (2013). Analisis Kritis Atas Laporan Keuangan. Cetakan Kesebelas. Jakarta: Rajawali Pers.

Hardiningsih, \& Pancawati. (2017). Pengaruh Faktor Fundamental dan Risiko Ekonomi Terhadap Return Saham pada Perusahaan di Bursa Efek Jakarta Studi Kasus Basic Industry \& Chemical. Jurnal Bisnis Strategi. 
Hariyanto, \& Dedi. (2017). Pengaruh Return on Asset, Return on Equity, dan Earning per Share Terhadap Return Saham Pembentuk Indeks Kompas 100. Jurnal Manajemen Motivasi.

Hartono. (2010). Teori Portofolio dan Analisis Investasi. Yogyakarta: BPFE UGM.

Hermawan, D. (2012). Pengaruh Debt To Equity Ratio (DER), Earning Per Share (EPS), Dan Net Profit Margin (NPM) Terhadap Return Saham Pada Perusahaan Perbankan yang Listing di BEI Pada Tahun 2008-2010. Management Analysis Journal, 1(5).

Ilmiyono, \& Agung, F. (2019). Pengaruh ROA, CR dan Quick Ratio terhadap Return Saham PT Astra Agro Lestari Tbk Periode 2007 - 2017. Jurnal Ilmiah Akuntansi Kesatuan.

Insani, \& Nurlailly, S. (2019). Analisis Pengaruh Faktor Fundamental Terhadap Return Saham. Jurnal Manajemen \& Keuangan.

Jabbari, E., \& Fathi, Z. (2014). Prediction of Stock Returns Using Financial Ratios Based on Historical Cost, Compared With Adjusted Prices (Accounting for Inflation) With Neural Network Approach. Indian Journal of Fundamental and Applied Life Sciences.

Karla, \& Roisantri. (2020). Pengaruh CR, NPM, DAR, dan ITO terhadap Return Saham pada Perusahaan Barang Konsumsi yang Terdaftar di BEI. Owner (Riset dan Jurnal Akuntansi).

Kasmir. (2014). Analisa Laporan Keuangan. Jakarta: PT. Raja Grafindo Utama.

Legiman, F. M. (2015). Faktor-faktor yang mempengaruhi return saham pada perusahaan agroindustry yang terdaftar di Bursa Efek Indonesia periode 2009-2012. Jurnal EMBA, Vol.3 No.3.

Menhard. (2018). Pengaruh Faktor Internal Terhadap Return Saham pada Kompas 100 di BEI 2015-2016. JWEM (Jurnal Wira Ekonomi Mikroskil.

Mudjijah, S. (2015). Analisis Pengaruh Faktor-Faktor Internal Perusahaan Terhadap Earning per Share. Jurnal Ekonomi dan Manajemen Vol.4 No.2.

Munawir. (2007). Analisis Laporan Keuangan (Edisi Keempat). Yogyakarta: Liberty.

Narayan. (2015). Comsumption and expected assets returns: an unobserved component approach. Macroeconomic Dynamics.

Nurdin, \& Emillia. (2018). Pengaruh Kinerja Keuangan Terhadap Return Saham pada Perusahaan Manufaktur yang Terdaftar di Bursa Efek Indonesia. Jurnal Mega Aktiva.

Nurmasari, I. (2018). Pengaruh Rasio Keuangan dan Pertumbuhan Pendapatan Terhadap Return Saham Pada Perusahaan Perkebunan Di Bursa Efek Indonesia 2010-2017. Jurnal SEKURITAS (Saham, Ekonomi, Keuangan, dan Investasi).

Pandji, B. I. (2019). Perbandingan Prediksi Harga Saham dengan model ARIMA dan Artificial Neural Network. Indoneisa Journal on Computing (Indo-JC), 4 (2), 189-198.

Prabath, U. (2014). The Impact of Accounting Variables On Stock Return: Evidence from Colombo Stock Exchange, Sri Lanka. International Journal of Business and Management Vol.9 No.5, 34-44. 
Prihantini, R. (2017). Analisis Pengaruh Inflasi, Nilai Tukar, ROA, DER, dan CR Terhadap Return Saham (Studi Kasus Saham Industri Real Estate and Property yang Terdaftar di Bursa Efek Indonesia Periode 2003-2006). Jurnal Bisnis Strategi.

Purnama, Tubagus, E., \& Asnawi. (2018). Pengaruh Faktor Fundamental Perusahaan Terhadap Return Saham. Jurnal Organisasi dan Manajemen.

Purnamasari, \& Imas. (2011). Pengaruh Kinerja Perusahaan Terhadap Return Saham. Jurnal ASET (Akuntansi Riset).

Puspitadewi, C., \& Rahyuda, H. (2016). Pengaruh DER, ROA, PER, dan EVA Terhadap Return Saham pada Perusahaan Food and Beverage di BEI. E-Jurnal Manajemen Unud Vol.5 No.3.

Putro, R. (2020). Effect of Debt to Asset Ratio, Return on Asset, and Earning per Share on Stock Return. Jurnal STEI Ekonomi Vol.XX No.XX.

Rois, \& Pandiya. (2019). Analisis Pengaruh Economic Value Added (EVA), Debt To Equity Ratio (DER), Return On Asset (ROA), dan Current Ratio (CR) terhadap Return Saham. Jurnal Sosial Humaniora dan Pendidikan (JSHP).

Salam, \& Aam, A. (2020). Pengaruh ROA, ROE, dan NIM Terhadap Return Saham Bank BUMN. Jurnal Dinamika Ekonomi \& Bisnis.

Septina, \& Siska. (2019). Pengaruh Faktor-Faktor Fundamental Terhadap Return Saham Perusahaan Jasa Transportasi. Jurnal Wawasan Manajemen.

Shakeel, M., \& Ali, G. (2018). Relationship Between Fundamental Analysis and Stock Return Based on the Panel Data Analysis; Evidence from Karachi Stock Exchange. Research Journal of Finance and Accounting, Vol. 9 No. 3.

Siburian, F. (2013). Analisis Pengaruh Debt to Equity Ratio (DER), Return on Assets (ROA) Terhadap Return Saham Pada Perusahaan Perbankan yang Terdaftar di Bursa Efek Indonesia. Jurnal Ekonomi dan Keuangan Vol. 1 No.6.

Simanjuntak, \& John, E. (2017). Analisis Pengaruh Debt to Equity Ratio (DER), Return on Asset (ROA), Ukuran Perusahaan, Inflasi, dan Nilai Tukar Terhadap Return Saham (Studi Kasus Pada Perusahaan Lembaga Keuangan Bank dan Lembaga Non Bank yang Listed di BEI Periode 2004-2007). Jurnal Bisnis Strategi.

Subarjo. (2015). Pengaruh Return on Asset (ROA), Current Ratio (CR), Net Profit Margin (NPM) dan Inflasi terhadap Harga Saham (Studi Kasus PT Kalbe Farma, Tbk. Periode Tahun 2001-2014). Jurnal Maksipreneur: Manajemen, Koperasi, dan Entrepreneurship.

Sugiarto, \& Agung. (2011). Analisa Pengaruh BETA, Size Perusahaan, DER, dan PBV Ratio Terhadap Return Saham. Jurnal Dinamika Akuntansi.

Sugiyono. (2009). Metode Penelitian Bisnis Pendekatan Kuantitatif Kualitatif dan R\&D. Bandung: Alfa Beta. 
Sunaryo, D., Supriatna, Y., \& Adiyanto, Y. (2019). Pengaruh Current Ratio dan Return on Equity (ROE) Terhadap Earning per Share (EPS). Jurnal Ilmiah Perbankan Syariah, Vol.5 No.2.

Tamuunu, S. (2015). The Influence of Fundamental Factors on Stock Return. Jurnal EMBA, Vol.3 No.4.

Tarmizi, \& Rosmiati. (2018). Pengaruh Likuiditas dan Profitabilitas Terhadap Return Saham. Jurnal Akuntansi dan Keuangan.

Umam, M., Wijayanto, E., \& Kodir, M. (2019). Analisis Pengaruh Current Ratio (CR), Debt to Equity Ratio (DER), Net Profit Margin (NPM), dan Firm Size Terhadap Earning per Share (EPS) (Studi pada Perusahaan Sektor Industri Dasar dan Kimia yang tercatat di BEI Periode 2014-2018). Keunis Majalah Ilmiah Vol.7 No.2.

Uno, \& Barlianta, M. (2014). Analisis Kinerja Keuangan, Ukuran Perusahaan, Arus Kas Operasional Pengaruhnya Terhadap Earning per Share. Jurnal Riset Ekonomi, Manajemen, Bisnis dan Akuntansi.

Wartono, T. (2018). Pengaruh Return on Asset dan Current Ratio Terhadap Earning per Share (Studi pada PT. Plaza Indonesia Realty, Tbk). Jurnal Semarak Vol.1 No.2.

Wicaksono, \& Maheranto. (2016). Analisis Pengaruh Kinerja Keuangan Terhadap Return Saham. Jurnal Ilmiah Mahasiswa FEB.

Yuni, R. R. (2016). Pengaruh Debt to Equity Ratio, Return on Asset, Net Profit Margin dan Current Ratio Terhadap Earning per Share Pada Perusahaan Manufaktur yang Terdaftar di BEI Periode 2011-2014. Bisma, Vol 1, No. 4. 